\title{
First record of the Indo-Pacific fish the Jarbua terapon (Terapon jarbua) (Osteichthyes: Terapontidae) in the Mediterranean with remarks on the wide geographical distribution of this species
}

\author{
DANIEL GOLANI ${ }^{1}$ and BRENDA APPELBAUM-GOLANI ${ }^{2}$ \\ ${ }^{1}$ Department of Evolution, Systematics and Ecology, The Hebrew University of Jerusalem, 91904 Jerusalem, Israel. \\ E-mail: dgolani@cc.huji.ac.il \\ ${ }^{2}$ Mt. Scopus Library, The Hebrew University of Jerusalem 91905 Jerusalem, Israel.
}

\begin{abstract}
SUMMARY: The Indo-Pacific fish Terapon jarbua is recorded for the first time in the Mediterranean. This record is evidentially the result of $T$. jarbua entering the Mediterranean via the Suez Canal (Lessepsian migration). The present record increases the total number of known Lessepsian fish to 74. A comparison of Mediterranean and Red Sea specimens of T. jarbua with specimens from the Far East suggests the necessity for genetic studies in order to clarify the unity of this taxon.
\end{abstract}

Keywords: Terapon jarbua, first record, Mediterranean, Indo-Pacific distribution.

RESUMEN: Primera Cita del PeZ Indo-Pacífico TeRapon JaRbua (Osteichthyes: Terapontidae) en el Mediterráneo CON COMENTARIOS SOBRE LA AMPLIA DISTRIBUCIÓN DE ESTA ESPECIE. - El pez indo-pacífico Terapon jarbua se ha recolectado por primera vez en el Mediterráneo. Este registro es evidentemente el resultado de la entrada de T. jarbua en el Mediterráneo vía el Canal de Suez (migración Lessepsiana). El presenta registro incrementa el número total de peces Lessepsianos a 74. La comparación de especímenes de T. jarbua mediterráneos y del mar Rojo de los de zona lejanas del Este sugiere la necesidad de estudios genéticos para poder clarificar la unidad de este taxon.

Palabras clave: Terapon jarbua, primera cita, Mediterráneo, distribución indo-pacífica.

\section{INTRODUCTION}

Invasion of the Mediterranean Sea by Red Sea species via the Suez Canal, termed Lessepsian migration, has accelerated in the last two decades (Golani, 2010). Documentation of new invaders is of utmost importance and contributes greatly to our understanding of this phenomenon that is considerably changing the biodiversity and ecosystem of the Eastern Mediterranean. In the most recent count, Golani (2010) enumerated 73 Lessepsian fish migrants with substantiated records. The present record brings the new total number to 74 .
The objectives of this study were to report the new record of Terapon jarbua from the Mediterranean with some morphomeristic comparison with specimens from the Red Sea, its evident source. In addition we performed a morphomeristic comparison of the specimens from the Red Sea with specimens from Japan and Hong Kong.

\section{MATERIALS AND METHODS}

On 25 July 2009 a specimen of Terapon jarbua (Forsskål, 1775) (Fig. 1) with a standard length of 170 


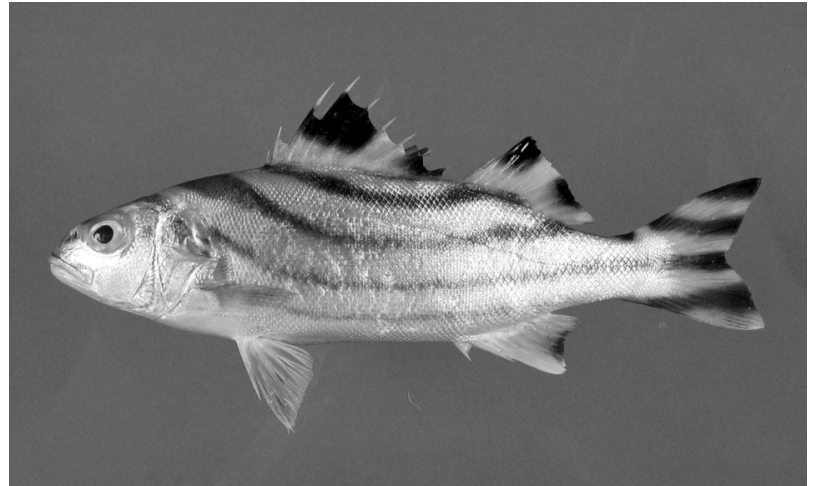

FIG. 1. - Terapon jarbua, $170 \mathrm{~mm}$ standard length, from Dor, Mediterranean coast of Israel, HUJ 19845.

$\mathrm{mm}$ (total length, $213 \mathrm{~mm}$ ) and a weight of $120.8 \mathrm{~g}$ was hooked in very shallow water $(c a .0 .5 \mathrm{~m})$ on the Mediterranean coast of Israel, at Dor (Tantura), ca. $25 \mathrm{~km}$ south of Haifa (Fig. 2). The specimen was deposited in the Hebrew University Fish Collection (HUJ) and received the catalogue number HUJ 19845.

Measurements and counts followed Hubbs and Lagler (1947). Measurements were taken with a dial calliper to the nearest $0.1 \mathrm{~mm}$. The head was measured to the most posterior point of the opercular margin, not taking in account the opercular spine. Predorsal and preanal distances were measured as the straight line from the tip of the premaxilla to the origin of dorsal and anal fins, respectively. Body depth was taken at first dorsal fin origin. The last dorsal and anal rays, which are divided almost to the base, were considered as one ray. Gill rakers were counted on the left side of the first gill arch. The raker at the arch's angle was counted with the lower arm. Lateral line scales were counted to the line of the hypural plate.

Other material examined: Northern Red Sea: HUJ 4705, $202 \mathrm{~mm}$, Elat, Gulf of Aqaba, Israel 1957; HUJ 5633, 201mm, ElBilayim, Gulf of Suez, Egypt, 19 Jan. 1972; HUJ 6652, $194 \mathrm{~mm}$, Elat, 1957; HUJ 14255, 84 mm, Elat, 9 Feb. 90; HUJ 14373 (3spec.) , 80-85 mm, Elat, 9 Mar. 90; HUJ 15970 (11 spec.), 165-217 mm, Nabeq, Gulf of Aqaba, Egypt 11 Nay 1968; HUJ 17971 (10 spec.), 162- $211 \mathrm{~mm}$, El Gharqana, Gulf of Aqaba, Egypt, 3 July 1969; HUJ 15972 (2 spec.), 147-182 mm, Elat, 14 July, 1965; HUJ 15973 (2 spec.), 147-182 mm, Elat, 1949; HUJ 19888 (2 spec.), 204-206 mm, Nabeq, 10 May, 1968. Southern Red Sea: HUJ 7345, 130 mm, Eritrea, 3 June 1961; HUJ 7347 (2 spec.), 127-135 mm, Eritrea, Dec. 1957; HUJ 15974, 113 mm, Eritrea, 16 Apr. 1962. Hong Kong: HUJ 14742 (2 spsc.), 115-157 mm, Hong Kong, 3 Feb. 1988. Japan: HUJ 19610, 117 mm, Meitsu Nango-cho, Miyazaki, 4 Aug. 2007; HUJ 19630 (5 spec.), 132-170 mm, Meitsu Nango-cho, Miyazaki, 7 Aug. 2007.

\section{RESULTS}

\section{Morphometric and meristic characteristics of the Mediterranean specimen}

Body oblong and slightly compressed. Head (29.5\%), depth at origin of dorsal fin $(28.2 \%)$, predorsal $(38.3 \%)$, preanal $(67.8 \%)$, least caudal peduncle $(10.3 \%)$, all percent of standard length. Blunt snout $(32.5 \%)$, eye moderately large $(25.9 \%)$, interorbital wide $(30.5 \%)$, all percent of head length. Mouth slightly oblique, jaws reaching back to the vertical of the anterior eye's margin. Villiform teeth with outer rows of enlarged teeth. A patch of teeth at the anterior of the upper jaw with eight elongated teeth in an outer row. No vomer or palatine teeth. Seven gill rakers on the upper arm of the first gill arch and 14 on the lower arm. The anterior nostril is slightly above the eye centre and round with a flap. Posterior nostril is vertically slit with a small flap at its posterior edge. Preoperculum is strongly serrated, especially at the angle. Post-temporal above gill opening with 13 serrae. Two flat opercular spines; the upper blunt and small and barely reaching the operculum margin. The lower spine is large and extends beyond the operculum margin. A well-developed and serrated cleithrum bone located between the pectoral fin and the lower opercular spine. Suborbital bone serrated.

Dorsal fin with a deep notch between spinous and the soft ray portion, 11 spines and 10 rays. The first spine is small, 2.4 times in the $2^{\text {nd }}$ spine and 6.7 times in the $4^{\text {th }}$, which is the largest spine. The penultimate dorsal spine is 1.7 times the last spine.

Anal fin with three spines, the last is the largest, and 8 soft rays; its posterior margin slightly concave. Caudal fin emarginated. Small pectoral fin with 12 rays. Pelvic find with one spine and fives rays, its origin clearly beyond the pectoral fin origin.

Body covered with small ctenoid scales, 73 in lateral line to the line of the hypural bones.

\section{Coloration of the Mediterranean specimen}

Body silvery-gray with four longitudinal stripes; the three upper stripes are black and curved downward; the upper stripe's origin is at the origin of the dorsal fin and terminating under the soft ray portion of the dorsal fin; the second stripe commences on the nape and ends at the posterior end of the dorsal fin; the third stripe runs from the occiput to the end of the middle of the caudal fin. The fourth stripe is straight, golden-yellow and starts at the origin of the pectoral fin and terminates at the ventral surface of the caudal peduncle. There is a large black spot on the upper part of the dorsal fin between the $3^{\text {rd }}$ and $6^{\text {th }}$ spines and a smaller spot is between the $8^{\text {th }}$ and $9^{\text {th }}$ spines. Two black spots are on the upper margin of the soft dorsal fin portion, the anterior between the $1^{\text {st }}$ and $3^{\text {rd }}$ rays and the second between the $6^{\text {th }}$ and $8^{\text {th }}$ rays. Caudal fin with black stripe in the middle, continuing the $3^{\text {rd }}$ longitudinal stripe. Two crossbands above and below it and broad black tip of the upper lobe. Black spot at the middle of the posterior edge of the anal fin. Pectoral and pelvic fin rays are white with transparent membrane, with a slight shade of orange on the $1^{\text {st }}$ and $2^{\text {nd }}$ rays of the pelvic fin.

The counts and measurements and colour pattern agree with the description of Terapon jarbua given by Vari (1984, 2001), Randall (1995) and others. 


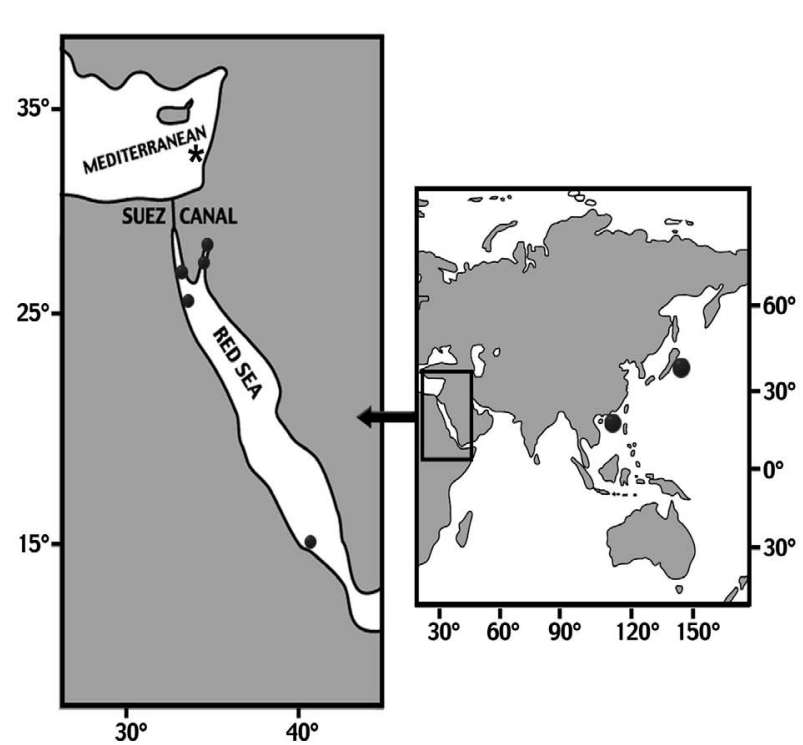

FIG. 2. - Locations of Terapon jarbua specimens in this study: solid dot $=$ records from original habitat; asterisk $=$ new record in the Mediterranean.

\section{DISCUSSION}

Terapon jarbua has a wide Indo-Pacific distribution from the Red Sea to Fiji and Japan (Vari, 2001). Like most other Lessepsian migrants, it was reported from the Gulf of Suez (Forsskål, 1775; Gruvel and Chabnaud, 1937), and several specimens preserved in the HUJ Collection have not been previously reported. Haas and Steinitz (1947) reported obtaining a specimen of $T$. jarbua in the Haifa fish market. However, Ben-Tuvia (1966) and Golani et al. (2002) concluded that this specimen evidently originated from Aqaba, since there was an active trade of fish from Aqaba to Haifa in the early 1940s. Until the present report, no specimen of $T$. jarbua had been reported from the Mediterranean.

The issue of the unity and identity of fish species with wide geographic distribution has been discussed in a number of studies (Randall, 1998; Gill and Kemp 2002). It has been estimated that close to $70 \%$ of Red Sea fish species have a wide Indo-Pacific distribution (Golani, 1999). However, according to Gill and Kemp (2002), many or most of the shore fishes currently considered as having a wide Indo-Pacific distribution actually belong to more than one taxon. These authors claim that the main reason for the prevailing opinion is the traditional taxonomic approach, which relied mainly on morphological analysis and the understanding that small differences were intra-specific due to geographic distances. More use of molecular studies may increasingly reveal that many species that were previously thought to have a wide geographic distribution may are in fact composed of two or more genetically distinct taxa which were termed cryptic species.
A comparison of the Red Sea specimens of Terapon jarbua with the specimens from Hong Kong and Japan reveals some slight differences. The upper longitudinal stripe of the Red Sea specimens is curved more downward than that of the Far Eastern specimens, thus leaving a relatively wide silvery-gray band at the base of the first dorsal fin, in contrast to almost reaching the base of the first dorsal fin (see, Kimura and Matsuura, 2003). The cleithrum bone of the Red Sea specimens reaches well beyond the lower opercular spine, while in the Far East specimens it reaches the tip of this spine or only slightly beyond it. In addition, the body depth of the Far Eastern and southern Red Sea specimens is slightly greater than that of the northern Red Sea fish, at least up to $180 \mathrm{~mm} \mathrm{SL} \mathrm{(Fig.3).} \mathrm{Furthermore,} \mathrm{the}$ number of lateral line scales is greater in the Far Eastern specimens (75-83) and southern Red Sea specimens (77-78) than in the northern Red Sea (68-76).

A similar trend has been observed in genetic studies of several other Indo-Pacific species also occurring in the Red Sea. The southern Red Sea population of the Hardyhead Atherinomorus lacunosus was found to be genetically closer to species in the western Pacific (Bucciarelli et al., 2002) than to those in the Mediterranean and the northern Red Sea; these northern Red Sea and Mediterranean fishes were previously considered to be co-specific but later elevated to a specific level (Kimura et al., 2007). Two unpublished studies of Sillago sihama and Saurida undosquamis reveal a similar pattern. The semi-enclosed Red Sea has partially isolated populations and is therefore likely to have genetically distinctive species, particularly in its northern sector, which also justifies further genetic studies regarding $T$. jarbua.

Terapon jarbua is the fourth teraponid to become a Lessepsian migrant. The previous Lessepsian teraponids were Pelates quadrilineatus (Bloch, 1790) and Terapon puta (Cuvier, 1829), both reported from the 1970s by Lourie and Ben-Tuvia (1970) and Ben-Tuvia (1977); they are still not very common in their new region. There is a surprising report of a single specimen of Terapon theraps Cuvier, 1829 from Piran, Slovenia (Lipej, 2008).

Terapon jarbua inhabits coastal waters over sandy substrates. Golani (1993) and Golani, et al. (2008) reported sub-adults from the sandy shore of the northern tip of the Gulf of Aqaba at depths of 0.5-1.5 m. This species is euryhalinic and known to inhabit brackish and freshwaters. It feeds upon small fishes and invertebrates. Randall (1995) and Vari (2001) reported that T. jarbua has the unique habit of feeding also upon the scales of fishes of other species. It is considered harmless to human beings but the Mediterranean specimen was reported as giving the fisherman "a good fight" and was still alive one hour after landing (Odeh, pers. comm.).

With the addition of the fourth terapon into the Mediterranean, it is appropriate to provide the following key for the species of this family that occur also in the Mediterranean Sea: 


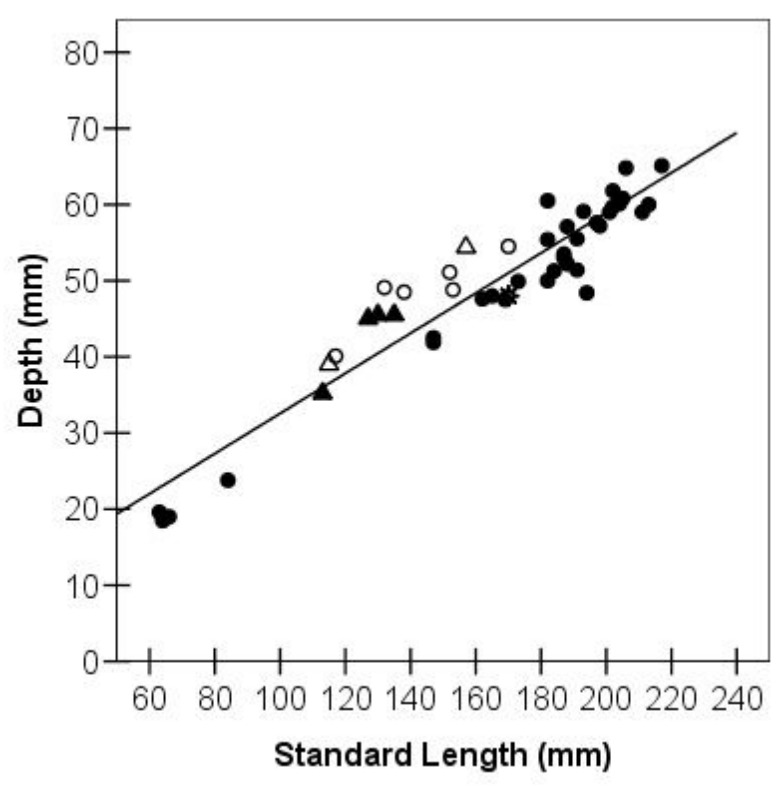

FIG. 3. - Standard Length versus Body Depth of Terapon jarbua populations; open circle, Japan; open triangle, Hong Kong; solid triangle, southern Red Sea; solid circle, northern Red Sea; asterisk, Mediterranean.

1. No stripes on the caudal fin; lower opercular spine does not extend beyond opercular edge. Pelates quadrilineatus

- Stripes on caudal fin; lower opercular spine extends beyond opercular edge. 2

2. Longitudinal stripes down-curved.Terapon jarbua

- Longitudinal stripes, straight. 3

3. Wide longitudinal stripes, their width equal to intervals between them Terapon theraps

- Narrow longitudinal stripes, their width much smaller than the intervals between them.

\section{Terapon puta}

\section{ACKNOWLEDGEMENTS}

We would like to thank Mr. Amir Odeh for providing the Mediterranean specimen and Mr. Alon Pasternak for informing us of the collection of this specimen. Special thanks go to Prof Y. Iwatsuki from the University of Miyazaki for providing us with the opportunity to collect the specimens from Japan and to A. Lerner for his help with the illustrations.

\section{REFERENCES}

Ben-Tuvia, A. - 1966. Red Sea fishes recently found in the Mediterranean. Copeia, 2: 254-275.
Ben-Tuvia, A. - 1977. New records of Red Sea immigrants in the eastern Mediterranean. Cybium, 3: 95-102.

Bucciarelli, G., D. Golani and G. Bernardi. - 2002. Genetic cryptic species as biological invaders: the case of a Lessepsian fish migrant, the hardyhead silverside Atherinomorus lacunosus. $J$. Exp. Mar. Biol. Ecol., 273: 143-149.

Forsskål, P. - 1775 Descriptiones Animalium; Avium, Amphibiorum, Piscium, Insectorum, Vermium, quae in Itinere Orientali Observavit. Petrus Forskål. Prof. Haun. Post mortem auctoris editit Carsten Niebuhr. Adjuncta est materia medica Kahirina atque tabula maris rubri geographica, 20+XXXIV+164 pp., 1 map; Hauniae, Copenhagen (Möller).

Gill, A.C. and J.M. Kemp. - 2002. Widespread Indo-Pacific shorefish species: a challenge for taxonomists, biogeographers, ecologists, and fishery and conservation managers. Envir. Biol. Fish., 65: 165-174.

Golani, D. - 1993. The sandy shore of the Red Sea-launching pad for Lessepsian (Suez Canal) migrant fish colonizers of the eastern Mediterranean. J. Biogeogr., 20: 579-585.

Golani, D. - 1999. The Gulf of Suez ichthyofauna - assemblage pool for Lessepsian migration into the Mediterranean. Isr. J. Zool., 45: 79-90.

Golani, D. - 2010. Colonization of the Mediterranean by Red Sea Fishes Via the Suez Canal - Lessepsian Migration. In: D. Golani and B. Golani-Appelbaum (eds.), Fish Invasions of the Mediterranean - Changes and Renewal, pp. 145-188. Pensoft, Sofia.

Golani, D., L. Orsi-Relini, E. Massutí, and J.-P. Quignard. - 2002. CIESM Atlas of exotic species in the Mediterranean. Vol. 1. Fishes. (F. Briand, ed.). CIESM Publisher, Monaco.

Golani, D., A. Lerner and B. Appelbaum-Golani. - 2008. Fish biodiversity in the sandy shore of the Gulf of Eilat in close proximity to nearby fish farm activity. In: D. Por (ed.), Aqaba-Eilat, the improbable gulf: environment, biodiversity and preservation. pp. 267-280. Magnes Press, Jerusalem.

Gruvel, A. and P. Chabanaud. - 1937. Missions A. Gruvel dans le Canal de Suez. II. Poissons. Mém. Ins. Egypte, 35: 1-31.

Haas, G. and H. Steinitz. - 1947. Erythrean fishes on the Mediterranean coast of Palestine. Nature, 160: 28.

Hubbs, C.L. and K.F. Lagler. - 1947. Fishes of the Great Lakes region. Bull. Cranbrook Inst. Sci., 26: 1-186.

Kimura, S. and K. Matsuura. (eds.). - 2003. Fishes of Bitung northern tip of Sulawesi, Indonesia. Ocean Research Institute, University of Tokyo, Tokyo.

Kimura, S., D. Golani, Y. Iwatsuki, M. Tabuchi, and T. Yoshino. - 2007. Redescriptions of the Indo-Pacific atherinid fishes Atherinomorus forskalii, Atherinomorus lacunosus, and Atherinomorus pinguis. Ichth. Res., 54: 145-159.

Lipej, L., B. Mavrič, V. Žiža and J. Dulčić. - 2008. The largescaled terapon Terapon theraps: a new Indo-Pacific fish in the Mediterranean Sea. J. Fish Biol., 73: 1819-1822.

Lourie, A. and A. Ben-Tuvia. - 1970. Two Red Sea fishes, Pelates quadrilineatus (Bloch) and Crenidens crenidens (Forsskål) in the eastern Mediterranean. Isr. J. Zool., 19: 203-207.

Randall, J.E. - 1995. Coastal fishes of Oman. Univ. Hawai'i Press, Honolulu.

Randall, J.E. - 1998. Zoogeography of shore fishes of the IndoPacific region. Zool. Stud., 37: 227-268.

Vari, R. - 1984. Teraponidae. In: W. Fischer and G. Bianchi (eds.), FAO species identification sheets for fishery purposes. Western Indian Ocean (Fishing Area 51). Vol. 4. FAO, United Nations, Rome.

Vari, R.P. - 2001. Teraponidae. In: K.E. Carpenter and V.H. Niem (eds.), FAO species identification guide for fisheries purposes. The living marine resources of the western central Pacific. Vol. 5. pp. 3305-3316. FAO, United Nations, Rome.

Scient. ed.: E. Massutí.

Received September 1, 2009. Accepted Frebuary 22, 2010.

Published online August 16, 2010. 